\title{
Response of Different Levels of Plant Spacing on Vegetative Growth and Yield Attributes of Ashwagandha (Withania somnifera) var. Poshita and Sarpagandha (Rauvolfia serpentina. Benth) var. Sheel under Open Environment and Orchard Conditions
}

\author{
S.S. Saravanan ${ }^{1}$, Deepak Lall ${ }^{1 *}$, Vijay Bahadur ${ }^{1}$ and Sanjeev Kumar ${ }^{2}$
}

${ }^{1}$ Department of Horticulture, Naini Agricultural Institute (NAI), Sam Higginbottom

University of Agriculture, Technology \& Sciences (SHUATS University), Prayagraj (Allahabad)-211007 (U.P.), India

${ }^{2}$ U.P. Council of Agricultural Research (UPCAR) Lucknow, U.P. India-220601

*Corresponding author

\begin{tabular}{|c|c|}
\hline & $\mathbf{T} R \mathbf{A} \mathbf{C} \mathbf{T}$ \\
\hline $\begin{array}{l}\text { K e y w o r d s } \\
\text { Ashwagandha, } \\
\text { Sarpagandha, Plant } \\
\text { Spacing, } \\
\text { Environment, Shade } \\
\text { conditions, Growth } \\
\text { and Yield }\end{array}$ & \multirow{3}{*}{$\begin{array}{l}\text { A field experiment was conducted during the two years research study. The experiment } \\
\text { shows the effect of different planting distance under open based and Anola shade condition } \\
\text { revealed that maximum vegetative growth viz., plant height }(104.84 \mathrm{~cm}) \text {, Number of leaves } \\
\text { per plant }(215.36) \text {, Number of branches per plant }(44.78) \text {, Root length }(51.05 \mathrm{~cm}) \text {, Shoot } \\
\text { length }(45.82 \mathrm{~cm}) \text {, Root fresh weight }(30.19 \mathrm{~g}) \text {, Root dry weight }(7.59 \mathrm{~g}) \text { and Total dry } \\
\text { matter production }(\mathrm{g}) \text { per plant }(25.14 \mathrm{~g}) \text { is associated with treatment } \mathrm{T}_{6}-\mathrm{S}_{6} \text { Ashwagndha } \\
\left(\mathrm{M}_{2} \mathrm{~S}_{2}\right) 70 \times 70 \mathrm{~cm} \text { (under Aonla shade condition), } \mathrm{T}_{8}-\mathrm{S}_{8} \text { Sarpagandha }\left(\mathrm{M}_{2} \mathrm{~S}_{4}\right) 50 \times 50 \mathrm{~cm} \\
\text { (under Aonla shade condition) along with } \mathrm{T}_{5}-\mathrm{S}_{5} \text { Ashwagndha }\left(\mathrm{M}_{2} \mathrm{~S}_{1}\right) 60 \times 60 \mathrm{~cm} \text { (under } \\
\text { Aonla shade condition). Whereas the highest yield and yield attributes parameters viz., } \\
\text { Root yield (g) per plant ( } 38.21 \mathrm{~g}) \text {, Root yield (kg) per plot }(2.53 \mathrm{~kg}) \text { and Root yield tones } \\
\text { per ha. }\left(1.69 \mathrm{t} / \mathrm{ha}^{-1}\right) \text { was observed maximum in treatment } \mathrm{T}_{8}-\mathrm{S}_{8} \text { Sarpagandha }\left(\mathrm{M}_{2} \mathrm{~S}_{4}\right) 50 \mathrm{x} \text { x } \\
50 \mathrm{~cm} \text { (under Aonla shade condition). While the maximum economics and Benefit: Cost } \\
\text { ratio i.e. }(1: 4.76) \text { was also found to be the highest with treatments } \mathrm{T}_{8}-\mathrm{S}_{8} \text { Sarpagandha }\left(\mathrm{M}_{2}\right. \\
\left.\mathrm{S}_{4}\right) 50 \times 50 \mathrm{~cm} \text { (under Aonla shade condition). }\end{array}$} \\
\hline & \\
\hline $\begin{array}{l}15 \text { June } \\
\text { Availab } \\
10 \text { July }\end{array}$ & \\
\hline
\end{tabular}

\section{Introduction}

Medicinal plants can be cultivated as pure crop, intercrop and border crop in plantation crops, perennial fruit orchards and agroforestry plantation system. Since the cultivable land is limited, efforts are needed to push these crops along with priority crops like Aonla and Guava orchards. Introduction of highly profitable medicinal crops into the existing cropping system without completely replacing the traditional crops is a strategy that is acquiring acceptance in India. According to one estimate of botanical survey of India, about 7,500 plants are used for medicinal purposes out of 15,000 plants of our country. There is a growing demand for medicines of Ayurveda, Siddha, Unani and Homeopathy both for domestic consumption and export purposes. Out of 80,000 tonnes of 
medicinal plants imported by Western countries, India tops the list of exporters to USA and Europe with a share of over 10,000 tonnes Kumar et al., (2007).

The values of trade in medicinal plants are about Rs. 5,000 crores, while the world trade is about US \$ 62 billion. India exports herbal products and medicines to the tune of Rs. 550 crores annually Reddy (2004). A survey indicated that the use of herbal medicines will reach to the tune of US \$ 5 trillion during 2050 Kumar and Singh (2003). Currently, the Ayurvedic and herbal products turnover is estimated to be Rs. 25,000 crores.

Ashwagandha (Withania somnifera), a member of family Solanaceae, in an important medicinal plant used for drugs mentioned in ancient ayurvedic literature. The plant is erect, herbaceous, evergreen to -mentose and branched under - shrub reaching upto15$170 \mathrm{~cm}$ of height. India officially recognized over 3000 plants for their medicinal values. India being one of the $12^{\text {th }}$ mega-diversity centers in the world, with this bio-resource wealth, it ranks 10th in the world and 4th in Asia having 15 to 20 thousand plants species with medicinal value of which 30 per cent are considered as endemic to India. Currently, there are about 880 species of medicinal plants in all India trade Kumar et al., (2007). Among the various medicinal plants, Withania somnifera is also known as 'Winter cherry' in English and 'Asgandh' in Hindi. Withania is an important medicinal plant and it is used in Ayurvedic and Unani systems of medicine extends back over 3000 to 4000 years. The crop is grown on marginal land and is also suitable for dry land farming (Hudge et al., 2002). The yield and quality in cultivated plants depend on several factors including environmental adaptability of particular cultivar or variety in specific area. Optimum plant density is important for best utilization of solar radiation and soil nutrients.
Plant growth regulators (PGRs) are known to alter the growth behavior, development and bio-synthesis of secondary metabolites in medicinal and aromatic plants (Audus, 1959; Steward and Kriikorian, 1971).

Rauvolfia roots or Serpentine roots are one of the important crude drugs used in modern medicine. The global market for medicinal plants has been growing and capitalizing on the growing awareness of herbal and aromatic plants worldwide. Rauvolfia serpentina (L.) Benth belongs to the family Apocyanaceae. There are approximately 85 species in the genus Rauvolfia found in tropical regions. Its leaves are simple, $7.5-10 \mathrm{~cm}$ long and $3.5-5$ $\mathrm{cm}$ broad. Root is prominent, tuberous, usually branched, 0.5 to $2.6 \mathrm{~cm}$ diameter, goes 40 to $60 \mathrm{~cm}$ deep into soil. The root bark, which constitutes $40-60 \%$ of the whole root, rich in $90 \%$ alkaloids. The fresh root emits a characteristic acrid aroma and is very bitter in taste. The plant grows generally in the region in the annual rainfall of 200-250 $\mathrm{cm}$ and upto an altitude of $1000 \mathrm{~m}$ and favors deep fertile soil with rich organic matter De and Dey, (2010). About 80 alkaloids are isolated from Rauvolfia species. The most important among these are reserpine, serpentine, rauvolfinine, ajmalicine, indobinine, reserpiline, serpagine, serpentinine, rescinamine, doserpidine, ajmaline, ajmalinine, sandwicolidine, ajmlicidine, yohimbine etc. (Deshmukh et al., 2012). The total alkaloid content varies from $1.7-3 \%$ of the dried roots depending upon varieties and cultivation practices. Rouvolfia has been categorized as an endangered species based on the IUCN Red Data Book and critically endangered in CAMP 2001 report Bhattarai et al., (2002) (Table 1).

Rauvolfia is used in Ayurveda, Siddha and Yunani sciences of medicines for the treatment of high blood pressure, insomnia, cardiac diseases and a number of mental 
problems such as psychic disorders, mental retardation, epilepsy, agitation and neurotic disorders. The powder of Sarpagandha roots is also used for the treatment of snakebites or snake poisoning. Root decoction and leaves are given to cure snakebite in Satar tribe of Morang and Jhapa districts Siwakoti and Siwakoti (2000). Extracts of the roots are valued for intestinal troubles; aqueous decoction of root is given to cattle in diarrhoea Dey (1998). Since the information on these aspects of Ashwagandha and sarpagandha is meager and have a standardization of agro-techniques for its cultivation and shall leads a long way to research works and practice of commercial cultivation among the growers. The present investigation on Ashwagandha and Sarpagandha was conducted to evaluate the Response of different levels of plant spacing on vegetative growth and yield performance of Ashwagandha (Withania Somnifera) var. Poshita and Sarpagandha (Rauvolfia serpentina. Benth) var. Sheel under open environment and orchard shade conditions.

\section{Materials and Methods}

A field experiment on research entitled "Response of different levels of plant spacing on vegetative growth and yield attributes of Ashwagandha (Withania Somnifera) var. Poshita and Sarpagandha (Rauvolfia serpentina. Benth) var. Sheel under open environment and orchard conditions" was conducted at Central Orchard, Horticulture Research Farm, Department of Horticulture, Naini Agricultural Institute (NAI), Sam Higginbottom University of Agriculture, Technology and Sciences, (SHUATS) Prayagraj (Allahabad) along with the support of financial assistance through U.P. Council of Agricultural Research (UPCAR) Lucknow, U.P. India. The area is situated on the south of Prayagraj (Allahabad) on the right bank of the river Yamuna at Rewa Road at a distance of about $6 \mathrm{Km}$ from Prayagraj city. It is positioned at $25.41^{\circ} \mathrm{N}$ latitude and $81.84^{\circ} \mathrm{E}$ longitude and about $98 \mathrm{~m}$ from above mean sea level. Prayagraj has sub-tropical climate, which prevails in the South-East part of Uttar Pradesh, with the both extremes of temperature i.e. the winters and the summers. In fairly cold winters (during Oct-Feb), the temperature falls to nearly $2-5^{0} \mathrm{C}$, sometimes below as $1^{0} \mathrm{C}$. During summer (March-June), the temperature raises upto $46^{\circ} \mathrm{C}$, sometimes peak $48-49^{\circ} \mathrm{C}$ with low relative humidity (20\%) and dust laden winds. During monsoon (June-Sept) it reaches $85 \%$ with average rainfall of $1100 \mathrm{~mm}$. The soil of experimental plot was well drained, fairly level land rich in sandy loam texture along with uniform fertility with optimum level of soil microbes' availability status along with low clay and higher percentage of sand particles. The experiment was design with 8 treatments and laid out in Randomized Block Design (RBD) with 3 replications on well prepared and pulverized piece of land. The allocation of these 8 treatment combination was done randomly. All the cultural practices related to Ashwagandha and Sarpagandha was conducted as per recommended requirement. Under this research work a nursery block was established to fulfill the availability and requirement of planting material throughout the research programme. Seedlings of Ashwagandha and Sarpagandha was raised through bed system technique (raised bed method) followed by establishment of 2000 plants each for Ashwagandha and Sarpagandha through cup system. The planting materials which was evolved is used for cultural operations like re-planting, gapfilling and transplanting under open condition and orchard based shade condition. The treatment combinations were formulated from two different spacings of Ashwagandha and Sarpagandha under open based enviornment and Aonla shade condition viz., $\mathrm{T}_{1^{-}}$ $\mathrm{S}_{1}$ Ashwagndha $\left(\mathrm{M}_{1} \mathrm{~S}_{1}\right) 60 \times 60 \mathrm{~cm}$ (under 
open condition), $T_{2}-S_{2}$ Ashwagndha $\left(M_{1} S_{2}\right)$ $70 \times 70 \mathrm{~cm}$ (under open condition), $\mathrm{T}_{3^{-}}$ $\mathrm{S}_{3}$ Sarpagandha $\left(\mathrm{M}_{1} \mathrm{~S}_{3}\right) 40 \times 50 \mathrm{~cm}$ (under open condition), $\mathrm{T}_{4}-\mathrm{S}_{4}$ Sarpagandha $\left(\mathrm{M}_{1} \mathrm{~S}_{4}\right)$ $50 \times 50 \mathrm{~cm}$ (under open condition), $\mathrm{T}_{5^{-}}$ $\mathrm{S}_{5}$ Ashwagndha $\left(\mathrm{M}_{2} \mathrm{~S}_{1}\right) 60 \times 60 \mathrm{~cm}$ (under Aonla shade condition), $\mathrm{T}_{6}-\mathrm{S}_{6}$ Ashwagndha $\left(\begin{array}{ll}\mathrm{M}_{2} & \mathrm{~S}_{2}\end{array}\right) \quad 70 \times 70 \mathrm{~cm}$ (under Aonla shade condition), $\mathrm{T}_{7}-\mathrm{S}_{7}$ Sarpagandha $\left(\mathrm{M}_{2} \mathrm{~S}_{3}\right) 40 \mathrm{x}$ $50 \mathrm{~cm}$ (under Aonla shade condition), $\mathrm{T}_{8^{-}}$ $\mathrm{S}_{8}$ Sarpagandha $\left(\mathrm{M}_{2} \mathrm{~S}_{4}\right) 50 \times 50 \mathrm{~cm}$ (under Aonla shade condition). The data were recorded on vegetative growth and yield attributes. The mean data of each character was subjected to statistical analysis of variance and test the significance of each character as per the procedure of Panse and Sukhatme (1967).

\section{Results and Discussion}

The Analysis of variance revealed significant differences among different treatment combination. A wide range of variations among the different combination of shade condition and different spacing of Ashwagandha and Sarpagandha in respect of Plant height $(\mathrm{cm})$, Number of leaves per plant, Number of branches per plant, Root length $(\mathrm{cm})$, Shoot length $(\mathrm{cm})$, Root fresh weight (g), Root dry weight (g) per plant, Total dry matter production $(\mathrm{g})$ per plant, Root yield $(\mathrm{g})$ per plant, Root yield $(\mathrm{kg})$ per plot and Root yield $\left(\mathrm{t} \mathrm{ha}{ }^{-1}\right)$ were recorded.

The maximum plant height $(104.84 \mathrm{~cm})$ was recorded in treatment $\mathrm{T}_{6}-\mathrm{S}_{6}$ Ashwagndha $\left(\mathrm{M}_{2}\right.$ $\left.\mathrm{S}_{2}\right) 70 \times 70 \mathrm{~cm}$ (under Aonla shade condition) and the minimum plant height $(59.14 \mathrm{~cm})$ was found in treatment $T_{3}-S_{3}$ Sarpagandha $\left(M_{1} S_{3}\right)$ $40 \times 50 \mathrm{~cm}$ (under open condition). Similar findings were also reported by Manish et al., (2003), Pakkiyanathan et al., (2004), Kahar et al., (1991) and Mohd. Abbas et al., (1994).

The maximum Number of leaves per plant (215.36) was recorded with $\mathrm{T}_{8}-\mathrm{S}_{8}$
Sarpagandha $\left(\mathrm{M}_{2} \mathrm{~S}_{4}\right) 50 \times 50 \mathrm{~cm}$ (under Aonla shade condition) and the minimum Number of leaves per plant (193.62) was found in treatment $T_{1}-S_{1}$ Ashwagndha $\left(M_{1} S_{1}\right)$ $60 \times 60 \mathrm{~cm}$ (under open condition). The maximum Number of branches per plant (44.78) was recorded in $\mathrm{T}_{5}-\mathrm{S}_{5}$ Ashwagndha $\left(\begin{array}{ll}M_{2} & S_{1}\end{array}\right) 60 \times 60 \mathrm{~cm}$ (under Aonla shade condition) and the minimum Number of branches per plant (22.65) was found in treatment $\mathrm{T}_{7}-\mathrm{S}_{7}$ Sarpagandha $\left(\mathrm{M}_{2} \mathrm{~S}_{3}\right) 40 \mathrm{x}$ $50 \mathrm{~cm}$ (under Aonla shade condition) were due to availability of more space, soil moisture and nutrients to individual plants. Similar findings were reported by Agarwal et al., (2003), Desai et al., (2017), Kahar et al., (1991) and Mohd. Abbas et al., (1994). The maximum Root length $(51.05 \mathrm{~cm})$ was concealed with in $\mathrm{T}_{8}-\mathrm{S}_{8}$ Sarpagandha $\left(\mathrm{M}_{2} \mathrm{~S}_{4}\right)$ $50 \times 50 \mathrm{~cm}$ (under Aonla shade condition) and the minimum Root length $(30.51 \mathrm{~cm})$ was found in treatment $T_{1}-S_{1}$ Ashwagndha $\left(M_{1} S_{1}\right)$ $60 \times 60 \mathrm{~cm}$ (under open condition). The maximum Shoot length $(45.82 \mathrm{~cm})$ was observed with $\mathrm{T}_{6}-\mathrm{S}_{6}$ Ashwagndha $\left(\mathrm{M}_{2} \mathrm{~S}_{2}\right) 70 \mathrm{x}$ $70 \mathrm{~cm}$ (under Aonla shade condition) and the minimum Shoot length $(39.07 \mathrm{~cm})$ was found in treatment $\mathrm{T}_{1}-\mathrm{S}_{1}$ Ashwagndha $\left(\mathrm{M}_{1} \mathrm{~S}_{1}\right) 60 \mathrm{x}$ $60 \mathrm{~cm}$ (under open condition). The maximum Root fresh weight $(30.19 \mathrm{~g})$ was pertain with $\mathrm{T}_{6}-\mathrm{S}_{6}$ Ashwagndha $\left(\mathrm{M}_{2} \mathrm{~S}_{2}\right) 70 \times 70 \mathrm{~cm}$ (under Aonla shade condition) and the minimum Root fresh weight $(\mathrm{g})(17.51 \mathrm{~g})$ was found in treatment $\mathrm{T}_{4}-\mathrm{S}_{4}$ Sarpagandha $\left(\mathrm{M}_{1} \mathrm{~S}_{4}\right) 50 \mathrm{x}$ $50 \mathrm{~cm}$ (under open condition).

These results were in conformity with the findings of Patel et al., (2004) and Desai et al., (2017), Kahar et al., (1991) and Mohd. Abbas et al., (1994). in Ashwagandha. The maximum Root dry weight $(\mathrm{g})(7.59 \mathrm{~g})$ was recorded in $\mathrm{T}_{8}-\mathrm{S}_{8}$ Sarpagandha $\left(\mathrm{M}_{2} \mathrm{~S}_{4}\right) 50 \mathrm{x}$ $50 \mathrm{~cm}$ (under Aonla shade condition) and the minimum Root dry weight $(5.66 \mathrm{~g})$ was found in treatment $\mathrm{T}_{1}-\mathrm{S}_{1}$ Ashwagndha $\left(\mathrm{M}_{1} \mathrm{~S}_{1}\right) 60 \mathrm{x}$ $60 \mathrm{~cm}$ (under open condition) (Fig. 1 and 2). 
Table.1 Impact of different levels of plant spacing on growth and yield attributes of Ashwagandha (Withania Somnifera) var. Poshita and Sarpagandha (Rauvolfia serpentina. Benth) var. Sheel under different open environment and shade condition

\begin{tabular}{|c|c|c|c|c|c|c|c|c|c|c|c|}
\hline Treatments & $\begin{array}{c}\text { Plant } \\
\text { height } \\
\text { (cm) }\end{array}$ & $\begin{array}{c}\text { No. of } \\
\text { leaves } \\
\text { per } \\
\text { plant }\end{array}$ & $\begin{array}{c}\text { No. of } \\
\text { branches } \\
\text { per plant }\end{array}$ & $\begin{array}{c}\text { Root } \\
\text { length } \\
(\mathbf{c m})\end{array}$ & $\begin{array}{c}\text { Shoot } \\
\text { lengt } \\
\text { h } \\
(\mathrm{cm})\end{array}$ & $\begin{array}{c}\text { Root } \\
\text { fresh } \\
\text { weight } \\
\text { (g) }\end{array}$ & $\begin{array}{c}\text { Root } \\
\text { dry } \\
\text { wt. } \\
(\text { g) } \\
\text { per } \\
\text { plant }\end{array}$ & $\begin{array}{c}\text { Total } \\
\text { dry } \\
\text { matter } \\
\text { produc } \\
\text { tion }(\mathrm{g}) \\
\text { per } \\
\text { plant }\end{array}$ & \begin{tabular}{|c|} 
Root \\
yield \\
$(\mathrm{g})$ \\
per \\
plan \\
$\mathbf{t}$
\end{tabular} & $\begin{array}{c}\text { Root } \\
\text { yield } \\
\text { (kg) } \\
\text { per } \\
\text { plot }\end{array}$ & $\begin{array}{l}\text { Root } \\
\text { yield } \\
(\mathbf{t} \text { ha- } \\
\left.\mathbf{1}^{\prime}\right)\end{array}$ \\
\hline $\begin{array}{l}T_{1}-S_{1} \text { Ashwagndha }\left(M_{1} S_{1}\right) 60 \times 60 \mathrm{~cm} \text { (under open } \\
\text { condition) }\end{array}$ & 104.29 & 193.62 & 42.40 & 30.51 & 39.07 & 28.34 & 5.66 & 24.34 & 9.17 & 0.43 & 0.27 \\
\hline $\begin{array}{l}T_{2}-S_{2} A s h w a g n d h a\left(M_{1} S_{2}\right) 70 \times 70 \mathrm{~cm} \text { (under open } \\
\text { condition) }\end{array}$ & 101.18 & 195.62 & 43.10 & 32.30 & 42.11 & 27.52 & 6.10 & 25.02 & 8.89 & 0.35 & 0.20 \\
\hline $\begin{array}{l}\mathrm{T}_{3}-\mathrm{S}_{3} \text { Sarpagandha }\left(\mathrm{M}_{1} \mathrm{~S}_{3}\right) 40 \times 50 \mathrm{~cm} \text { (under open } \\
\text { condition) }\end{array}$ & 59.14 & 207.85 & 23.08 & 46.11 & 0.00 & 19.50 & 7.06 & 0.00 & 13.04 & 1.49 & 1.33 \\
\hline $\begin{array}{l}\mathrm{T}_{4}-\mathrm{S}_{4} \text { Sarpagandha }\left(\mathrm{M}_{1} \mathrm{~S}_{4}\right) 50 \times 50 \mathrm{~cm} \text { (under open } \\
\text { condition) }\end{array}$ & 61.11 & 212.74 & 23.29 & 47.09 & 0.00 & 17.51 & 7.44 & 0.00 & 34.16 & 2.20 & 1.41 \\
\hline $\begin{array}{l}\mathrm{T}_{5}-\mathrm{S}_{5} \text { Ashwagndha } \\
\text { Aonla shade) }\end{array}$ & 104.05 & 198.93 & 44.78 & 33.48 & 43.21 & 29.25 & 6.33 & 25.14 & 9.51 & 0.50 & 0.32 \\
\hline $\begin{array}{llll}\mathrm{T}_{6}-\mathrm{S}_{6} \text { Ashwagndha } & \left(\mathrm{M}_{2} \mathrm{~S}_{2}\right) & 70 \times 70 \mathrm{~cm} & \text { (under } \\
\text { Aonla shade) } & & \end{array}$ & 104.84 & 202.58 & 43.63 & 36.47 & 45.82 & 30.19 & 6.80 & 24.80 & 10.17 & 0.69 & 0.22 \\
\hline $\begin{array}{l}\mathrm{T}_{7}-\mathrm{S}_{7} \text { Sarpagandha } \\
\text { Aonla shade) }\end{array}$ & 61.20 & 211.49 & 22.65 & 50.63 & 0.00 & 18.50 & 7.52 & 0.00 & 32.31 & 1.85 & 1.50 \\
\hline $\begin{array}{l}\mathrm{T}_{8}-\mathrm{S}_{8} \text { Sarpagandha }\left(\mathrm{M}_{2} \mathrm{~S}_{4}\right) 50 \times 50 \mathrm{~cm} \text { (under } \\
\text { Aonla shade) }\end{array}$ & 62.32 & 215.36 & 23.49 & 51.05 & 0.00 & 19.75 & 7.59 & 0.00 & 38.21 & 2.53 & 1.69 \\
\hline F-test & $S$ & $S$ & $\mathrm{~S}$ & $S$ & $S$ & S & $S$ & $S$ & $S$ & $\mathrm{~S}$ & $S$ \\
\hline C.D. at 05 & 0.031 & 0.051 & 0.049 & 0.111 & 0.051 & 0.048 & 0.394 & 0.394 & 10.729 & 0.041 & 9.657 \\
\hline Sed. & 0.014 & 0.024 & 0.023 & 0.052 & 0.024 & 0.022 & 0.183 & 0.183 & 5.003 & 0.019 & 4.502 \\
\hline
\end{tabular}


Table.2 Economics with Benefit: Cost ratio of Ashwagandha and Sarpagandha as a (intercrops) under different treatments.

\begin{tabular}{|c|c|c|c|c|c|c|c|}
\hline $\begin{array}{l}\text { Tr. } \\
\text { Symbol }\end{array}$ & Treatment Combinations & $\begin{array}{c}\text { Cost of } \\
\text { cultivatio } \\
\mathbf{n} \\
\left(\text { Rs. } \text { ha }^{-1}\right)\end{array}$ & $\begin{array}{c}\text { Root } \\
\text { Yield } \\
\left(\mathbf{t} / \mathbf{h a}^{-1}\right)\end{array}$ & $\begin{array}{c}\text { Root } \\
\text { Selling } \\
\text { (Rate/kg) }\end{array}$ & $\begin{array}{c}\text { Gross } \\
\text { Return } \\
(\text { Rs. Qt / ha' })\end{array}$ & $\begin{array}{l}\text { Net return } \\
\left(\text { Rs. Qt } / \text { ha }^{-1}\right)\end{array}$ & $\begin{array}{c}\text { B:C } \\
\text { Ratio }\end{array}$ \\
\hline $\mathbf{T}_{1}$ & $\mathrm{~T}_{1}-\mathrm{S}_{1}$ Ashwagndha $\left(\mathrm{M}_{1} \mathrm{~S}_{1}\right) 60 \times 60 \mathrm{~cm}$ (under open condition) & 33,834 & 0.27 & 175 & 47250 & 13416 & 1: 1.40 \\
\hline $\mathbf{T}_{2}$ & $\mathrm{~T}_{2}-\mathrm{S}_{2}$ Ashwagndha $\left(\mathrm{M}_{1} \mathrm{~S}_{2}\right) 70 \times 70 \mathrm{~cm}$ (under open condition) & 33,834 & 0.20 & 175 & 35000 & 1166 & 1: 1.03 \\
\hline $\mathbf{T}_{3}$ & $\mathrm{~T}_{3}-\mathrm{S}_{3}$ Sarpagandha $\left(\mathrm{M}_{1} \mathrm{~S}_{3}\right) 40 \times 50 \mathrm{~cm}$ (under open condition) & 88,700 & 1.33 & 250 & 332500 & 243800 & $1: 3.75$ \\
\hline $\mathbf{T}_{4}$ & $\mathrm{~T}_{4}-\mathrm{S}_{4}$ Sarpagandha $\left(\mathrm{M}_{1} \mathrm{~S}_{4}\right) 50 \times 50 \mathrm{~cm}$ (under open condition) & 88,700 & 1.41 & 250 & 352500 & 263800 & 1: 3.97 \\
\hline $\mathbf{T}_{5}$ & $\begin{array}{l}\mathrm{T}_{5}-\mathrm{S}_{5} \text { Ashwagndha }\left(\mathrm{M}_{2} \mathrm{~S}_{1}\right) 60 \times 60 \mathrm{~cm} \text { (under Aonla shade } \\
\text { condition) }\end{array}$ & 33,834 & 0.32 & 175 & 56000 & 22166 & 1: 1.66 \\
\hline $\mathbf{T}_{6}$ & $\begin{array}{l}\mathrm{T}_{6}-\mathrm{S}_{6} \text { Ashwagndha }\left(\mathrm{M}_{2} \mathrm{~S}_{2}\right) 70 \times 70 \mathrm{~cm} \text { (under Aonla shade } \\
\text { condition) }\end{array}$ & 33,834 & 0.22 & 175 & 38500 & 4666 & $1: 1.14$ \\
\hline $\mathbf{T}_{7}$ & $\begin{array}{l}\mathrm{T}_{7}-\mathrm{S}_{7} \text { Sarpagandha }\left(\mathrm{M}_{2} \mathrm{~S}_{3}\right) 40 \times 50 \mathrm{~cm} \text { (under Aonla shade } \\
\text { condition) }\end{array}$ & 88,700 & 1.50 & 250 & 375000 & 286300 & $1: 4.23$ \\
\hline $\mathbf{T}_{8}$ & $\begin{array}{l}\mathrm{T}_{8}-\mathrm{S}_{8} \text { Sarpagandha }\left(\mathrm{M}_{2} \mathrm{~S}_{4}\right) 50 \times 50 \mathrm{~cm} \text { (under Aonla shade } \\
\text { condition) }\end{array}$ & 88,700 & 1.69 & 250 & 422500 & 333800 & $1: 4.76$ \\
\hline
\end{tabular}


Fig.1 Influence of different levels of plant spacing on vegetative growth parameters of Ashwagandha (Withania Somnifera) var. Poshita and Sarpagandha (Rauvolfia serpentina. Benth) var. Sheel under different environmental condition

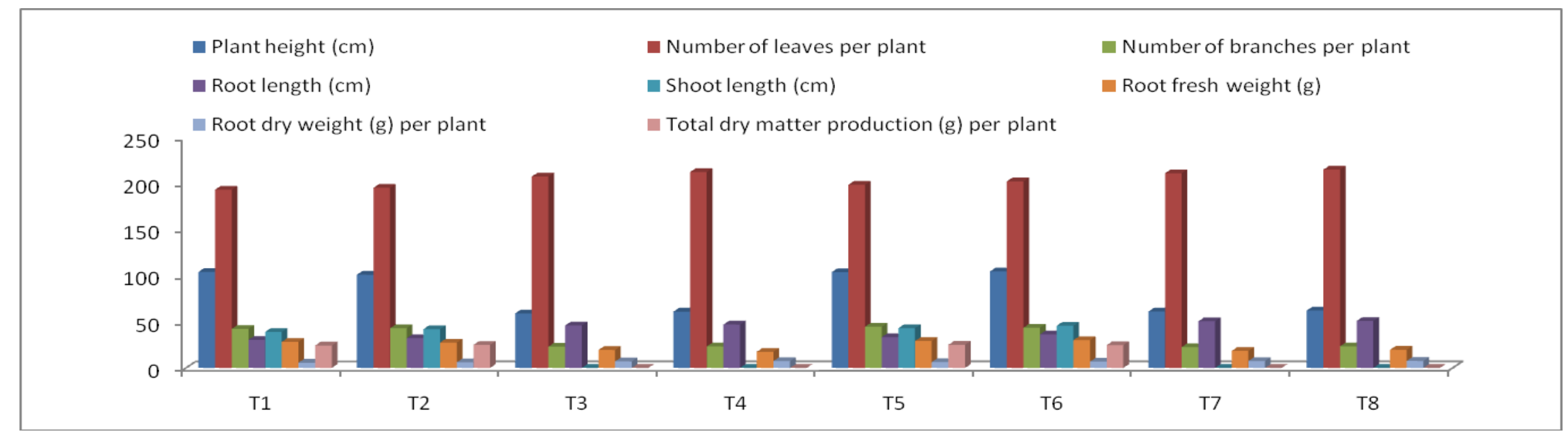

Fig.2 Effect of different levels of plant spacing on yield performance of Ashwagandha (Withania Somnifera) var. Poshita and Sarpagandha (Rauvolfia serpentina. Benth) var. Sheel under open environment and shade condition

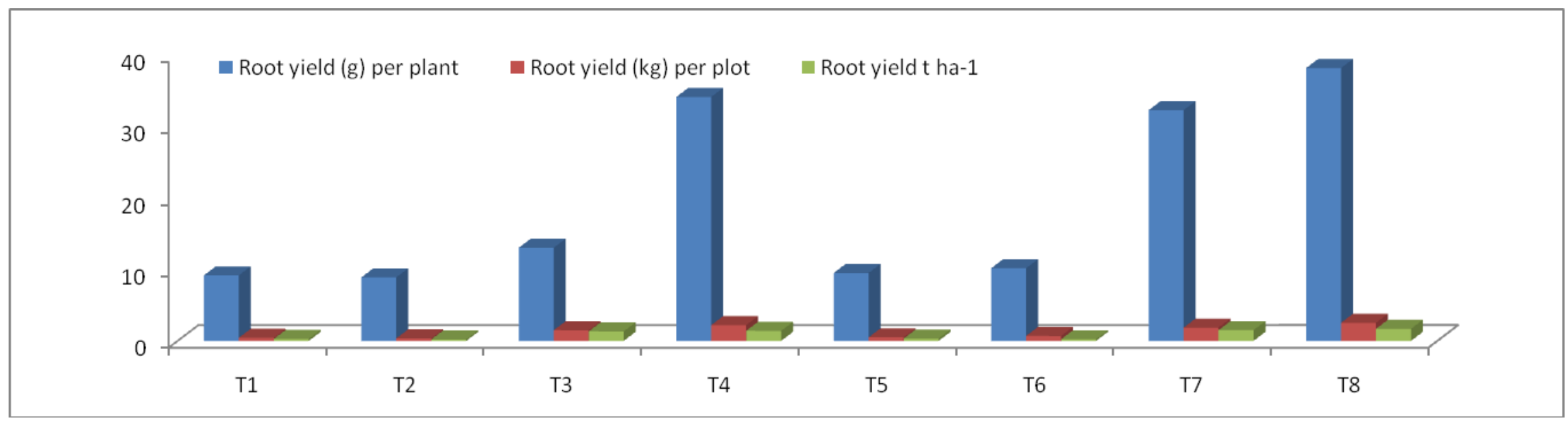


The maximum Total dry matter production per plant $(25.14 \mathrm{~g})$ was recorded with $\mathrm{T}_{5^{-}}$ $\mathrm{S}_{5}$ Ashwagndha $\left(\mathrm{M}_{2} \mathrm{~S}_{1}\right) 60 \times 60 \mathrm{~cm}$ (under Aonla shade condition) and the minimum Total dry matter production per plant (24.34g) was found in treatment $\mathrm{T}_{1}-\mathrm{S}_{1}$ Ashwagndha $\left(\mathrm{M}_{1} \mathrm{~S}_{1}\right) 60 \times 60 \mathrm{~cm}$ (under open condition). These results are in accordance with Kubsad et al., (2008), Kahar et al., (1991), Mohd. Abbas et al., (1994), Desai et al., (2017). The maximum Root yield per plant $(38.21 \mathrm{~g}$ ) was recorded in $\mathrm{T}_{8}-\mathrm{S}_{8}$ Sarpagandha $\left(\mathrm{M}_{2} \mathrm{~S}_{4}\right) 50 \mathrm{x}$ $50 \mathrm{~cm}$ (under Aonla shade condition) and the minimum Root yield per plant $(9.17 \mathrm{~g})$ was concealed with treatment $\mathrm{T}_{1}-\mathrm{S}_{1}$ Ashwagndha $\left(\mathrm{M}_{1} \mathrm{~S}_{1}\right) 60 \times 60 \mathrm{~cm}$ (under open condition). The maximum Root yield per plot $(2.53 \mathrm{~kg})$ was recorded with $\mathrm{T}_{8}-\mathrm{S}_{8}$ Sarpagandha $\left(\mathrm{M}_{2} \mathrm{~S}_{4}\right)$ $50 \times 50 \mathrm{~cm}$ (under Aonla shade condition) and the minimum Root yield per plot $(0.35 \mathrm{~kg})$ was pertain with treatment $\mathrm{T}_{2}-\mathrm{S}_{2}$ Ashwagndha $\left(\mathrm{M}_{1} \mathrm{~S}_{2}\right) 70 \times 70 \mathrm{~cm}$ (under open condition). The maximum Root yield (1.69 $\left.\mathrm{t} / \mathrm{ha}^{-1}\right)$ with the application $\mathrm{T}_{8}-\mathrm{S}_{8}$ Sarpagandha $\left(\mathrm{M}_{2} \mathrm{~S}_{4}\right) 50$ $x 50 \mathrm{~cm}$ (under Aonla shade condition) and the minimum Root yield $\left(0.20 \mathrm{t} / \mathrm{ha}^{-1}\right)$ were found in treatment $T_{2}-S_{2}$ Ashwagndha $\left(M_{1} S_{2}\right) 70 \mathrm{x}$ $70 \mathrm{~cm}$ (under open condition). Similar results were also observed by Maheshwari et al., (2000) and Desai et al., (2017). The above results are in close conformity with those of Kahar et al., (1991) and Mohd. Abbas et al., (1994).

The data presented in Table 2 indicated that the response of different plant spacing under different environmental condition (Open and Aonla shade). The maximum Gross return (422500), Net return (333800) and Benefit: cost ratio (1:4.76) was observed highest with treatment $\mathrm{T}_{8}-\mathrm{S}_{8}$ Sarpagandha $\left(\mathrm{M}_{2} \mathrm{~S}_{4}\right) 50 \mathrm{x}$ $50 \mathrm{~cm}$ (under Aonla shade condition) along with highest Gross return (56000), Net return (22166) and Benefit: cost ratio (1:1.66) was found best in treatment $\mathrm{T}_{5} \mathrm{~S}_{5}$ Ashwagndha $\left(M_{2} S_{1}\right) 60$ x $60 \mathrm{~cm}$ (under Aonla shade condition) respectively. Based on the above findings and economic returns, it is concluded that the potential production of Ashwagandha and Sarpagandha can be secured by raising the crop with a different plant spacing under suitable environmental condition of Prayagraj (Allahabad) agro-climatic region. The above results are in close conformity with those Kapur et al., (2010), Srinivasappa et al., (1999) and Chandrashekhar et al., 2007).

In conclusion, the demand, acceptability and market value of Sarpgandha and Ashwagandha is increasing rapidly for medicinal utility around the globe. The modern scientific agro-cultivation approaches of Ashwagandha and Sarpagandha practiced as an intercrop with different plant spacing under different environmental conditions (Open \& shade) has a great impact on successive vegetative growth, yield potential and market profitability in India. Replacing traditional practices, systematic agricultural activities can play a significant role in maintaining the status of environment.

Hence the above experimental findings concluded that Ashwagandha and Sarpagandha when accommodate with different planting distance i.e. $\mathrm{T}_{8^{-}}$ $\mathrm{S}_{8}$ Sarpagandha $\left(\mathrm{M}_{2} \mathrm{~S}_{4}\right) 50$ x $50 \mathrm{~cm}$ (under Aonla shade condition), $\mathrm{T}_{5}-\mathrm{S}_{5}$ Ashwagndha $\left(M_{2} S_{1}\right) 60$ x 60cm (under Aonla shade condition) and $\mathrm{T}_{6}-\mathrm{S}_{6}$ Ashwagndha $\left(\mathrm{M}_{2} \mathrm{~S}_{2}\right) 70$ $\mathrm{x} 70 \mathrm{~cm}$ (under Aonla shade condition) was recorded the best treatment combination interms of maximum vegetative growth and Root yield. While the highest economics and $\mathrm{B}: \mathrm{C}$ ratio $(1: 4.76)$ was obtained with treatments $\mathrm{T}_{8}-\mathrm{S}_{8}$ Sarpagandha $\left(\mathrm{M}_{2} \mathrm{~S}_{4}\right) 50 \mathrm{x}$ $50 \mathrm{~cm}$ (under Aonla shade condition). Therefore investigation of this research project reveals that Ashwagandha \& Sarpagandha are grown as an intercrops which shows high economic returns, more foreign exchange, high benefit: cost ratio. 
Whereas these crops are also very much found to be viable, adaptable, tolerant against water stress, heat stress, resistant against several insect-pest \& diseases and also they were recommended for its commercial cultivation under existing perennial Aonla orchard.

\section{Acknowledgment}

The authors are very much delighted, grateful and thankful to the U.P. Council of Agricultural Research (UPCAR), Lucknow, and Department of Horticulture, Sam Higginbottom University of Agriculture, Technology and Sciences, (SHUATS), Prayagraj (Allahabad), Uttar Pradesh211007, India for providing all necessary helps, facilities and financial assistance during the course of whole research investigation.

\section{References}

Agarwal M.; Singh, P. and Gupta, A. K., 2003. Economic evaluation of different treatment combinations of sowing time and spacing in Ashwagandha. Current Agriculture, 27 (1-2): 109-110.

Audus, L. J. (1959). Plant growth substances ed. Polumn N. Leonard Hill Ltd. Pp. 328 .

Bhattarai NK, Tandon V and Ved DK 2002. Highlights and outcomes of the conservation assessment and management plan (CAMP) workshop. In: Proceedings, Regional Workshop on Sharing Local and National Experience in Conservation of Medicinal and Aromatic Plants in South Asia (NK Bhattarai and M Karki eds), 21-23 January 2001, Pokhara, Nepal, IDRC/MAPPA, New Delhi, India and Ministry of Forests and Soil Conservation, Kathmandu, Nepal, pp 46-53.
Chandrashekhar Rao S, Nagireddy, Chandrasekhar R, Rajkumar M. (2007) Effect of type of cutting, method of planting and spacing on establishment and root yield of medicinal coleus (Coleus forskohlii). National Symposium on Medicinal and Aromatic Plants for Economic Benefit of Rural People MAPER, 2007, 19.

Desai, P. B. 2003. Effect of planting dates on seed yield and quality of ashwagandha (Withania somnifera Dunal), M.sc (Agri). Thesis submitted to MPKV, Rahuri, Maharashtra.

Hudge, V. S., Shobhane, M. R., Dhoble, M. V. and Dhote, A. M. (2002). Suitable medicinal and aromatic crop plants for dry land farming. Agro. Technology for Dry Land Farming. Pp. 593-612

Kahar, L.S., Tomar, S.S., Pathan, M.A. arid Nigam, K.B. 1991. Effect of sowing date and variety on root yield of aswagandha. Indian Journal of Agricultural Sciences 61: 495.

Kapur, L.T., Sutariya, K.K. and Zala, S.U. (2010). Effect of spacing on yield attributes and yield of ashwagandha, Internat. J. Forestry and Crop Improv., 1 (2): 123-126.

Kubsad, V. S., Palled, Y. B., Mansur, C. P. and Alagundagi, S.C. 2008. Influence of spacing and fertilizer levels on growth and dry matter production in ashwagandha. Madras Agric. J., 97 (79): 212-215.

Kumar A, Kaul MK, Bhan MK, Khanna PK, Suri KA. (2007). Morphological and chemical variation in 25 collections of the Indian medicinal plant, Withania somnifera (L.) Dunal (Solanaceae). Genetic Resources and Crop Evolution. 2007; 54(3): 655-660

Kumar S, Singh D. (2003). Gene effects and genotypes $\mathrm{x}$ environment interaction at various growth stages of different biomass characters in Indian mustard. 
National Journal of Plant Improvement. 2003; 5(2): 112-115.

Maheshwari, S. K., Sharma, R. K. and Gangrade, S.K., 2000.Response of ashwagandha to organic manures and fertilizers in shallow black soil under rainfed conditions. Indian Journal of Agronomy, 45 (1): 214-216.

Manish Agarwal, Agarwal, M. K. Singh, P. and Gupta, A. K. (2003). Economic evaluation of different treatment combination of sowing time and spacing in ashwagnadha. Current Agriculture. 27(1/2): 109-110.

Mohd. Abbas, Tomar, S.S. and Nigam, K.B. 1994. Effect of plant densities and cultivars of aswagandha on its productivity. Research and Development Reporter II: 26-28.

Pakkiyanathan, K. Pasha, Y. N., Reddy Y. N. and Sathe, A., (2004) Effect of spacing and phosphorus level on growth and root yield of Ashwagandha (Withania somnifera Dunal) Indian. J. Hort. 61(2): 195-197.

Patel, D.H., Upadyaya, P.N., Patel, K.V., Patel, J.B. and Patel, B.K. 2004. Effect of method of sowing, time of harvesting and nitrogen application on dry root yield of ashwagandha (Withania somnifera Dunal). J. Med. Aro. Pl. Sci., 26: 288-292.

Reddy YV. (2004) Growth analysis of medicinal plants. Indian Journal of Plant Physiology. 2004; 2(1): 87-89.

Srinivasappa KN, Krishnan R, Farooqi AA, Mahadevu P. (1999). Performance of diploid and induced autotetraploid Solanum viarum at varying plant densities. Journal of Medicinal and Aromatic Plant Sciences. 1999; 21(4): 1085-1089.

\section{How to cite this article:}

Saravanan, S.S., Deepak Lall, Vijay Bahadur and Sanjeev Kumar. 2019. Response of Different Levels of Plant Spacing on Vegetative Growth and Yield Attributes of Ashwagandha (Withania somnifera) var. Poshita and Sarpagandha (Rauvolfia serpentina. Benth) var. Sheel under Open Environment and Orchard Conditions. Int.J.Curr.Microbiol.App.Sci. 8(07): 2065-2074. doi: https://doi.org/10.20546/ijcmas.2019.807.248 